\title{
Czas wolny dzieci niepełnosprawnych intelektualnie w opinii rodziców
}

ABSTRACT: Izabella Kaiser, Czas wolny dzieci niepetnosprawnych intelektualnie w opinii rodziców [Leisure time of intellectually disabled students in the opinion of their parents]. Interdyscyplinarne Konteksty Pedagogiki Specjalnej, nr 17, Poznań 2017. Pp. 35-51. Adam Mickiewicz University Press. ISSN 2300-391X

The study aimed at diagnosing the opinions of parents of children with mild and moderate intellectual disability on the forms and significance of leisure time behaviour. The study revealed that parents, siblings, or other family members were most often partners of leisure for intellectually disabled children. All the respondents declare that they know what their children are doing in their leisure time and who they spend it with. Leisure time appears to be the area of limitless rehabilitation opportunities, and therefore it should occupy a significant position both in scientific research and (perhaps predominantly) in practical activities undertaken to help children with intellectual disability. Extensive activity of the school, family environment and special education teachers themselves is required to implement leisure time as a vital element in the process of revalidation of intellectually disabled children.

KEY WORDS: family, leisure time, intellectual disability

\section{Wprowadzenie}

We współczesnej cywilizacji czas wolny jest jedną z najwyżej cenionych wartości, która wywiera wpływ na osobowość człowieka i decyduje o jakości życia. Jego rozmiary traktowane są jako 
znaczący wyznacznik dobrobytu społecznego, rozwoju kulturalnego, a nawet poziomu zdrowotności w krajach czy grupach społecznych.

Rosnąca z dnia na dzień coraz większa ilość czasu wolnego zmusza nie tylko pojedynczego człowieka, ale także całe społeczeństwo do zainteresowania się nowymi treściami działalności ludzkiej, która ogarniać będzie ten rozszerzający się obszar¹. Racjonalne zagospodarowanie czasu wolnego wpływa bowiem na wszechstronny rozwój osobowości, podniesienie sprawności fizycznej, rozładowuje stany napięcia emocjonalnego, służy odbudowie fizycznych i psychicznych sił człowieka.

Kwestie wypełniania i właściwego zużytkowania czasu wolnego stają się istotnym problemem społecznym. W nowoczesnej rodzinie, borykającej się niejednokrotnie z trudnościami materialnymi i organizacyjnymi, racjonalne rozwiązanie problemu wolnego czasu nie jest łatwe. W wielu środowiskach rodzinnych obserwuje się brak zainteresowania tym zagadnieniem. Nie wszyscy rodzice rozumieją korzyści wynikające $\mathrm{z}$ prawidłowego spędzania wolnych chwil i roli, jaką odgrywają one w rozwoju osobowości dziecka. Aneta Jegier $^{2} \mathrm{z}$ niepokojem sygnalizuje spotykane coraz częściej zjawiska społeczne określane jako "syndrom dziecka zagospodarowanego" czy „dziecka zaniedbanego z dobrobytu”.

Zachowania wolnoczasowe, szczególnie ich aspekt rozwojowy i rewalidacyjny, powinny być szczegółowo analizowane na gruncie oligofrenopedagogiki. Coraz powszechniejsze jest zrozumienie, iż rozwój osób niepełnosprawnych intelektualnie musi być wszechstronny. Nie można zatem mówić o adaptacji społecznej tych jednostek bez uwzględnienia jednej z podstawowych płaszczyzn procesu rewalidacji, jakim jest racjonalne spędzanie czasu wolnego.

${ }^{1}$ K. Czajkowski, Wychowanie do rekreacji, Wydawnictwa Szkolne i Pedagogiczne, Warszawa 1979.

2 A. Jegier, Wprowadzenie, [w:] Czas wolny małych dzieci w świecie realnym $i$ wirtualnym, red. A. Jegier, Difin SA, Warszawa 2016. 
W kontekście tak zasygnalizowanej problematyki istotne wydaje się być podjęte $\mathrm{w}$ badaniach empirycznych poznanie opinii rodziców odnośnie do czasu wolnego ich niepełnosprawnego intelektualnie dziecka.

\section{Czas wolny dziecka niepełnosprawnego intelektualnie}

Czas wolny dziecka różni się od czasu wolnego człowieka dorosłego. Musi być inny, bo zgoła odmienna jest sytuacja społeczno-ekonomiczna dziecka i osoby dorosłej. Zachowania wolnoczasowe młodej jednostki podlegają i podlegać powinny kontroli rodziców czy wychowawców ze względu na to, że dziecko cechuje brak dojrzałości psychicznej oraz mniejszy bagaż doświadczeń3.

W pedagogice specjalnej przyjmuje się, że czas wolny osób niepełnosprawnych intelektualnie to ten okres dnia, który po uwzględnieniu czasu przeznaczonego na naukę $\mathrm{w}$ szkole lub wypełnienie obowiązków zawodowych, elementarną regenerację organizmu oraz specjalne zabiegi rehabilitacyjne, a także niezbędne czynności domowe, pozostaje do ich wyłącznej dyspozycji i może być okresem samodzielnych wyborów odnośnie do rodzajów i terenu zajęć związanych $\mathrm{z}$ wypoczynkiem, rozrywką i zaspokojeniem osobistych zainteresowañ ${ }^{4}$. Należy pamiętać, że ilość czasu wolnego

${ }^{3}$ K. Czajkowski, Wychowanie do rekreacji, WSiP, Warszawa 1979.

${ }^{4} \mathrm{H}$. Borzyszkowska, Zajęcia pozalekcyjne i poza szkolne oraz czas wolny dzieci upośledzonych umystowo, [w:] Upośledzenie umystowe, pedagogika, red. K. Kirejczyk, PWN, Warszawa 1981, rozdz. 14; L. Ploch, Jak organizować czas wolny dzieci i młodzieży upośledzonych umysłowo, WSiP, Warszawa 1992; M. Parchomiuk, Sposoby spędzania czasu wolnego przez młodzież upośledzona umysłowo w stopniu lekkim $i$ sprawna umystowo, „Wychowanie Na co Dzień” 2000, nr 4/5 s. 13-16; T. Żółkowska, Aktywność pozadydaktyczna uczniów z lekkim stopniem upośledzenia umysłowego a poziom opieki rodziców nad ich czasem wolnym, "Zeszyty Naukowe. Prace Instytutu Pedagogiki i Psychologii" 1995, nr 21, s. 115-128; J. Zimny, Czas wolny wyzwaniem rodziny w kształtowaniu osobowości osób niepetnosprawnych, [w:] Rodzina w oczach społeczeństwa, red. J. Zimny, Katolicki Uniwersytet Lubelski Jana Pawła II w Lublinie, Stalowa Wola 2013, s. 9-27. 
dzieci z niepełną sprawnością intelektualną jest zmniejszona $\mathrm{w}$ wyniku udziału w różnych dodatkowych zajęciach o charakterze rewalidacyjnym, takich jak logopedia, zabiegi rehabilitacyjne, korekcyjne czy reedukacyjne. Ponadto dzieci te ze względu na zaburzenia rozwoju umysłowego, brak doświadczeń życiowych, niedojrzałość społeczną są bardziej uzależnione od swoich rodziców czy opiekunów. W konsekwencji nie mogą w pełni samodzielnie i zgodnie ze swoją wolą organizować sobie czasu wolnego.

W odniesieniu do osób niepełnosprawnych intelektualnie Leszek Ploch ${ }^{5}$ wskazuje cztery aspekty czasu wolnego:

- wychowawczo-psychologiczny; dobrze zorganizowany czas wolny może pomóc w zakresie rozwoju umysłowego, moralno-społecznego i fizycznego, ułatwia kontakty i przeżycia społeczne, stwarza okazję do poznawania i rozumienia otaczającego świata, budzi potrzebę współdziałania $\mathrm{z}$ innymi, wzbogaca intelektualnie;

- opiekuńczy, czyli wspieranie wszechstronnego rozwoju jednostki, niesienie pomocy w zakresie bezpieczeństwa, zdrowia, zapobiegania trudnościom i niepowodzeniom oraz ulepszania środowiska życia;

- higieniczno-zdrowotny; sposób spędzania czasu wolnego bardzo wyraźnie wpływa na odprężenie psychofizyczne organizmu;

- rewalidacyjny, rozumiany jako stwarzanie sytuacji, w których osoby z ograniczoną sprawnością intelektualną muszą przejawiać inicjatywę, aktywność i umiejętność organizowania sobie zajęć dodatkowych.

L. Ploch zauważa dalej, iż „możemy przypuszczać, że duże znaczenie wychowawcze, psychologiczne, opiekuńcze i rewalidacyjne czasu wolnego wynika z powiązania strony operacyjno-poznawczej procesu kształcenia w toku swobodnej i niczym nieskrępowanej działalności ze stroną motywacyjną upośledzonych umysłowo"6.

${ }^{5}$ L. Ploch, Jak organizować czas wolny dzieci i młodzieży upośledzonych umysłowo, WSiP, Warszawa 1992.

6 Ibidem, s. 16. 


\section{Rola rodziny $w$ kształtowaniu form spędzania czasu wolnego}

Oddziaływanie środowiska społecznego na jednostkę odbywa się $\mathrm{w}$ toku procesu socjalizacji. Zrozumiałe jest, że środowisko to w zależności od panujących w nim norm, zasad, systemu wartości, obyczajów, zwyczajów, poglądów czy przekonan - może wywierać pozytywny lub negatywny wpływ na styl życia człowieka.

Grupą pierwotną, która odgrywa podstawowe znaczenie socjalizacyjne, jest rodzina.

Jako naturalne środowisko ma ona duże możliwości m.in. w zakresie analizowanego przygotowania dziecka do racjonalnego korzystania z czasu wolnego np. poprzez zachęcanie do aktywności fizycznej, osobistą postawę, przekazywanie umiejętności sportowych, stwarzanie warunków do uczestnictwa w rodzinnej rekreacji, umożliwianie korzystania z ośrodków rekreacyjnych i kulturalnych. Rodzina uczy dokonywania wyborów, kształtuje zainteresowania i nawyki rekreacyjne.

Najistotniejszy sens doświadczania czasu wolnego tkwi przede wszystkim w pełnej swobodzie jego wyboru. Należy jednak pamiętać, że nie można takiej swobody udzielić osobie, która nie utrwaliła w sobie wartościowych dążeń oraz nawyków. Dziecko w wieku 13-14 lat ma oczywiście już znaczną zdolność do działań samodzielnych, organizowania sobie czasu wolnego oraz pracy nad sobą w sposób służący wszechstronnemu rozwojowi. Nadal jednak na kształtowanie wypoczynku dorastającej, ale wciąż niedojrzałej jeszcze jednostki znaczący wpływ mają i mieć muszą poglądy rodziców, ich przekonanie o korzystnych sposobach zagospodarowania czasu wolnego oraz zakresie swobody niezbędnej dziecku w wyborze i realizacji zajęć wolnoczasowych. Jednakże udział opiekuna $\mathrm{w}$ wychowaniu i kierowaniu aktywnością $\mathrm{w}$ czasie wolnym musi uwzględniać wolę młodego pokolenia poszukującego własnego stylu rozrywki.

${ }^{7}$ J. Gracz, T. Sankowski, Psychologia w rekreacji i turystyce, Akademia Wychowania Fizycznego w Poznaniu, Poznań 2001. 
Rola rodziny $\mathrm{w}$ wychowaniu i procesie socjalizacji dziecka niepełnosprawnego intelektualnie jest szczególna, gdyż jak zauważa Władysław Dykcik: „opieka nad nim jest wyjątkowo poważnym problemem ze względu na złożoność i względną trwałość schorzenia oraz konieczność wczesnego diagnozowania, usprawniania oraz usamodzielniania prowadzonego $\mathrm{w}$ warunkach domowych" ${ }^{\prime \prime}$. Wzrasta także stopień trudności w realizowaniu zadań i funkcji, które rodzina ma spełnić wobec dziecka niepełnosprawnego umysłowo.

Istotną sferą oddziaływań jest przygotowanie do racjonalnego spędzania czasu wolnego, gdyż w środowisku rodzinnym kształtują się już od najmłodszych lat umiejętności zabawy, rozrywki i wypoczynku, rozwijają się pierwsze pozabiologiczne potrzeby i zainteresowania; tu dziecko niepełnosprawne intelektualnie jest przyuczane do spędzania czasu wolnego.

Na rodzicach spoczywa obowiązek racjonalnego sterowania jego organizacją. Niemniej w tak ukierunkowanych oddziaływaniach wychowawczych konieczne jest przestrzeganie pryncypialnych zasad obowiązujących w oligofrenopedagogice, takich jak:

- dostosowanie zajęć czasu wolnego do potrzeb, zainteresowań oraz możliwości psychofizycznych dziecka,

- dobrowolność uczestnictwa,

- motywowanie do podejmowania aktywności,

- atrakcyjność proponowanych zajęć czasu wolnego,

- wszechstronna aktywizacja,

- stopniowanie trudności i etapowość w realizowaniu zadań organizowanego czasu wolnego,

- poglądowość metod i form, treści opracowanych i wykorzystanych w zajęciach wolnoczasowych,

- ciągłość i systematyczność sprawowania opieki,

- zapewnienie higieny i bezpieczeństwa.

${ }^{8}$ W. Dykcik, Tendencje rozwoju pedagogiki specjalnej. Osiagnięcia naukowe i praktyka, Wydawnictwo Naukowe Polskiego Towarzystwa Pedagogicznego, Poznań 2010, s. 162 . 
Nie każda rodzina może i potrafi prawidłowo przygotowywać swoje dzieci do umiejętnego zarządzania czasem wolnym. Pod tym względem L. Ploch ${ }^{9}$ mówi o trzech typach rodzin:

- rodziny świadomie aktywne, które stwarzają konkretne warunki do kształtowania umiejętności organizowania czasu wolnego; rodzice uczestniczą $\mathrm{w}$ zajęciach wolnoczasowych i mają świadomość swego udziału $\mathrm{w}$ procesie rewalidacji dziecka z niepełną sprawnością intelektualną;

- rodziny, które udzielają wsparcia na miarę swych możliwości, ale inicjatywę pozostawiają placówkom i instytucjom; sporadyczny jest ich udział w zajęciach wolnoczasowych dzieci;

- rodziny bierne, które nie przywiązują wagi do racjonalnego, kulturalnego i zorganizowanego spędzania czasu wolnego.

Trudną i niezwykle ważną sprawą jest kontrola sposobu spędzania czasu wolnego przez osoby niepełnosprawne intelektualnie. Jak zauważa wspomniany L. Ploch ${ }^{10}$ dość często zdarza się, że czas ten nie jest ani zorganizowany, ani nadzorowany przez dorosłych. Stwarza to poważne zagrożenie dla bezpieczeństwa dzieci i młodzieży, a także dla ich rozwoju zdrowotnego i psychospołecznego.

\section{Założenia badań własnych}

W kontekście tak zasygnalizowanych aspektów czasu wolnego bardzo ważne wydaje się być - podjęte $\mathrm{w}$ badaniach empirycznych - poznanie opinii rodziców na temat zachowań wolnoczasowych ich niepełnosprawnego intelektualnie dziecka.

W celu pozyskania materiału badawczego zastosowano metodę sondażu diagnostycznego. $W$ przeprowadzonych badaniach posłużono się techniką ankiety dla rodziców na temat form zachowań

${ }^{9}$ L. Ploch, Jak organizować czas wolny dzieci i mtodzieży upośledzonych umystowo, WSiP, Warszawa 1992.

${ }^{10}$ L. Ploch, op. cit. 
wolnoczasowych, ilości czasu wolnego oraz udziału dzieci w zajęciach pozalekcyjnych i pozaszkolnych. Materiał empiryczny zebrano w 2017 r. wśród rodziców uczniów Szkoły Podstawowej Specjalnej im. Marii Montessori w Zespole Szkół Specjalnych nr 102 w Poznaniu. W skład grupy badawczej weszło 50 rodziców uczniów niepełnosprawnych intelektualnie w stopniu lekkim - 52,6\% (24 rodziców dziewczynek i 26 chłopców) oraz 45 rodziców dzieci z niepełnosprawnością intelektualną umiarkowaną - 47,3\% (20 rodziców dziewczynek i 25 chłopców). Wiek dzieci, których dotyczyły badania kształtował się od 7 do16 lat. Zdecydowana większość z nich $(83,1 \%)$ ma rodzeństwo. Badani rodzice prezentują zróżnicowany poziom wykształcenia. Najliczniejszą grupę stanowili rodzice z wyższym $(42,1 \%)$ oraz średnim $(29,5 \%)$ wykształceniem.

\section{Analiza wyników badań}

Pierwszym badanym zagadnieniem były opinie rodziców odnośnie do budżetu czasu wolnego ich dzieci w trakcie dni nauki szkolnej, w okresach weekendowych oraz podczas ferii zimowych i wakacji letnich.

Tabela 1. Ilość czasu wolnego w tygodniu w opinii rodziców (\%)

\begin{tabular}{|l|c|c|}
\hline \multirow{2}{*}{$\begin{array}{c}\text { Ilość czasu } \\
\text { wolnego }\end{array}$} & \multicolumn{2}{|c|}{$\begin{array}{c}\text { Opinie rodziców dziecka } \\
\text { z niepełnosprawnością intelektualną }\end{array}$} \\
\cline { 2 - 3 } & w stopniu lekkim & w stopniu umiarkowanym \\
\hline $0,5-1 \mathrm{~h}$ & 4,0 & 2,2 \\
\hline $2-3 \mathrm{~h}$ & 64,0 & 31,1 \\
\hline Więcej niż 3 h & 32,0 & 66,7 \\
\hline Nie ma czasu wolnego & - & - \\
\hline Razem & 100,0 & 100,0 \\
\hline
\end{tabular}

Źródło: badania własne 
Przeprowadzone badania wskazują, że w tygodniu nieco więcej czasu wolnego zdaniem większości rodziców mają dzieci z umiarkowaną niepełnosprawnością intelektualną. Są to ponad 3 godziny. Ich rówieśnicy z lekką niepełnosprawnością intelektualną dysponują 2-3 godzinami czasu wolnego $\mathrm{w}$ dniach nauki szkolnej. Można przypuszczać, iż wynika to z większego obciążenia ich zadania domowymi. Uczniowie z lekką niepełnosprawnością realizują bowiem Podstawę Programową Kształcenia Ogólnego obowiązującą w szkołach ogólnodostępnych, co implikuje m.in. konieczność intensywnej nauki również $\mathrm{w}$ domu.

Pozytywnie należy ocenić fakt, że żaden z rodziców nie wskazał sytuacji, w której ich syn/córka nie ma czasu wolnego. Należy bowiem pamiętać, że dziecko niesprawne umysłowo często uczestniczy w rozmaitych zajęciach dodatkowych o charakterze rewalidacyjnym, takich jak logopedia, zabiegi rehabilitacyjne czy reedukacyjne, co mogłoby implikować nadmierne ograniczenie ich czasu przeznaczonego na zajęcia dowolne. A jak dowodzą Andrzej Kusztelak i Karoliny Ląg, z punktu widzenia prawidłowego rozwoju każdego ucznia „musi istnieć równowaga pomiędzy organizacją pracy a wypoczynkiem”, a ich niewłaściwy rytm „powoduje osłabienie organizmu, zmniejszenie odporności na choroby, szybkie męczenie się, pogorszenie koordynacji nerwowo-mięśniowej, występowanie bólów mięśniowych lub stawowych"11.

Kolejnym okresem, który przeanalizowano w kontekście rodzicielskiej oceny ilości czasu wolnego były weekendy.

Wyniki przedstawione w tabeli 2. wskazują, że niezależnie od stopnia niepełnosprawności intelektualnej dzieci - zdaniem przeważającej części rodziców podczas weekendów dysponują bardzo dużą ilością czasu wolnego - ponad 6 godzin.

11 A. Kusztelak, K. Ląg, Czas wolny młodzieży aksjologicznym dylematem edukacji dla bezpieczeństwa, [w:] Edukacja dla bezpieczeństwa. Interdyscyplinarne konteksty $i$ dylematy, red. Z. Dziemanko, A. Kusztelak, Wydawnictwa Naukowe Wyższej Szkoły Handlu i Usług, Poznań 2010, s. 65. 
Tabela 2. Ilość czasu wolnego w weekendy w opinii rodziców (\%)

\begin{tabular}{|l|c|c|}
\hline \multirow{2}{*}{ Ilość czasu wolnego } & \multicolumn{2}{|c|}{$\begin{array}{c}\text { Opinie rodziców dziecka } \\
\text { z niepełnosprawnością intelektualną }\end{array}$} \\
\cline { 2 - 3 } & w stopniu lekkim & w stopniu umiarkowanym \\
\hline 1-2 h & - & - \\
\hline 3-4 h & 10,0 & 8,9 \\
\hline 5-6 h & 20,0 & 17,8 \\
\hline Więcej niż 6 h & 70,0 & 73,3 \\
\hline Nie ma czasu wolnego & - & - \\
\hline Razem & 100,0 & 100,0 \\
\hline
\end{tabular}

Źródło: badania własne

Wakacje letnie i ferie zimowe $\mathrm{w}$ ocenie rodziców to dla dzieci przede wszystkim czas bez obowiązków.

Tabela 3. Ilość czasu wolnego podczas wakacji w opinii rodziców (\%)

\begin{tabular}{|c|c|c|c|}
\hline \multirow{2}{*}{\multicolumn{2}{|c|}{ Ilość czasu wolnego }} & \multicolumn{2}{|c|}{$\begin{array}{c}\text { Opinie rodziców dziecka z niepełnosprawnością } \\
\text { intelektualną }\end{array}$} \\
\hline & & w stopniu lekkim & w stopniu umiarkowanym \\
\hline \multirow{6}{*}{ 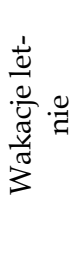 } & $1-2 \mathrm{~h}$ & - & - \\
\hline & $3-5 \mathrm{~h}$ & - & - \\
\hline & $6-8 \mathrm{~h}$ & 24,0 & 37,8 \\
\hline & cały dzień & 76,0 & 62,2 \\
\hline & nie ma czasu wolnego & - & - \\
\hline & Razem & 100,0 & 100,0 \\
\hline \multirow{6}{*}{ 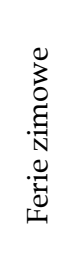 } & $1-2 \mathrm{~h}$ & - & - \\
\hline & $3-5 \mathrm{~h}$ & 16,0 & - \\
\hline & $6-8 \mathrm{~h}$ & 30,0 & 22,2 \\
\hline & Cały dzień & 54,0 & 77,8 \\
\hline & Nie ma czasu wolnego & - & - \\
\hline & Razem & 100,0 & 100,0 \\
\hline
\end{tabular}

Źródło: badania własne 
Z przeprowadzonych badań wynika, że w percepcji większości rodziców dzieci niezależnie od stopnia niepełnoprawności intelektualnej podczas wakacji letnich i zimowych mają wolny cały dzień. Pojawia się zatem bardzo poważny problem, jakim jest wakacyjny wypoczynek dziecka niepełnosprawnego. Zdarza się, że wyjedzie ono na kolonię, obóz czy turnus rehabilitacyjny. Jednak to są dwa, trzy tygodnie $\mathrm{z}$ dwumiesięcznego letniego wypoczynku. Pozostały okres pozostaje do dyspozycji rodziców, do przemyślanego działania na rzecz niepełnosprawnego intelektualnie dziecka w celu zaplanowania zajęć, które będą dla niego ciekawe, bezpieczne oraz rozwojowe.

Konieczność właściwego, racjonalnego zagospodarowania czasu wolnego podkreśla Wiesław Siwiński, dowodząc, że "sprawą niezmiernie ważną jest nie tylko to, ile człowiek przeciętnie ma czasu wolnego, ale i to, jak go spożytkuje, jakie formy będą zastosowane, czy rekompensują one wysiłek wkładany $\mathrm{w}$ pracę $\mathrm{i} \mathrm{w}$ jakiej mierze wpływają na rozwój jednostki, jej zdrowie, postępowanie oraz wyniki w pracy"12.

Uwzględniając przytoczoną opinię, w dalszej części badań podjęto problem form, $w$ jakich czas wolny spędzają dzieci niepełnosprawne intelektualnie.

Ankietowani rodzice deklarują, że ich dzieci podejmują aktywność ruchową. 98,9\% badanych wskazuje aktywne spędzanie czasu wolnego podczas weekendów i wakacji, a $86,6 \%$ również w tygodniu. W grupie aktywnych form rekreacji w czasie wolnym $w$ tygodniu, weekendy oraz wakacje nie stwierdzono większych różnic. Najbardziej popularne okazały się spacery $(70 \%)$, pływanie, $(50 \%)$, jazda na rowerze (50\%) oraz taniec $(30 \%)$. W formach weekendowowakacyjnych badani rodzice wskazywali dodatkowo wycieczki piesze i wyjazdy poza miejsce zamieszkania, jazdę konną oraz bieganie. Małą popularnością natomiast cieszy się jazda na rolkach czy wrotkach, gra w piłkę i wycieczki rowerowe. Stopień niepełno-

12 R.D. Tauber, W. Siwiński, Pedagogika czasu wolnego, Wyższa Szkoła Hotelarstwa i Gastronomii, Poznań 2002, s. 32. 
sprawności intelektualnej dziecka nie różnicował wskazywanych przez rodziców aktywnych form zachowań wolnoczasowych.

Mimo że ankietowani rodzice deklarują aktywny sposób spędzania czasu wolnego przez ich dzieci, to również wskazują odpoczynek bierny. Wśród tych form wypoczynku nie zdiagnozowano większych różnic między zachowaniami w tygodniu, w weekendy oraz w czasie wakacji. Zdecydowanie najczęściej rodzice wskazywali oglądanie telewizji $(70 \%)$, malowanie i rysowanie $(60 \%)$ oraz słuchanie muzyki lub słuchowisk (60\%). W pojedynczych tylko wskazaniach pojawiło się spanie oraz bezczynność i nuda. Dodatkowo podczas weekendów i wakacji dzieci chodzą do kina $(20 \%)$ i grają w gry planszowe (20\%). Dość nieoczekiwanym wynikiem jest fakt, że zdecydowanie częściej takie formy biernego wypoczynku, jak surfowanie po internecie i granie w gry komputerowe oraz czytanie książek i czasopism sygnalizowali rodzice dzieci z umiarkowaną niepełnosprawnością intelektualną.

Z pragmatycznego punktu widzenia bardzo ważna jest analiza pytania otwartego, w którym respondenci eksponowali własne propozycje form spędzania czasu dla przyjemności, które postrzegają jako odpowiednie dla swoich dzieci. Spośród aktywnych form zachowań wolnoczasowych najczęściej ankietowani wymieniali spacery, gry i zabawy na Orlikach, zwiedzanie miast i okolicy, grę w piłkę, jazdę na rowerze, wycieczki piesze i rowerowe. Należy zaznaczyć jednocześnie, iż zdaniem rodziców dobre są również bierne formy wypoczynku, takie jak kontrolowane oglądanie telewizji, gry komputerowe, czytanie książek, zajęcia manualne (malowanie, rysowanie, lepienie), zajęcia artystyczne, gry planszowe, gry logiczne, słuchanie muzyki, wyjścia do kina czy teatru. W odniesieniu do najmłodszych dzieci rodzice bardzo często (80,2\%) wskazywali również swobodną zabawę jako dobroczynną formę spędzania czasu wolnego wykorzystywaną z powodzeniem do kompensowania deficytów rozwojowych u osób niepełnosprawnych intelektualnie. Uzyskany wynik należy interpretować z dużym uznaniem, gdyż zgodnie z założeniami pedagogiki zabawy taka forma aktywności ma pierwszorzędne znaczenie w procesie wychowania i kształ- 
cenia osób z niepełnosprawnością. Opinie rodziców odnośnie właściwych zachowań wolnoczasowych nie różnicował stopień niepełnosprawności intelektualnej ich dziecka.

Niezwykle istotne i cenne jest, że w wielu wypowiedziach rodzice podkreślali znaczenie spędzania czasu wolnego razem z dziećmi niezależnie od stopnia ich niepełnosprawności intelektualnej. Wskazywali zatem rodzinne wycieczki, wspólne gry czy czytanie książek lub bajek, zabawy z rodzeństwem. Uzyskane wyniki pozwalają z nieco większym optymizmem interpretować wyraźnie negatywne konkluzje Ruty Pięty i Beaty Matacz ${ }^{13}$, które sygnalizują okazjonalne tylko kontakty dziecka z rodzicami w czasie wolnym. Dziecko, zdaniem autorek, większość czasu spędza na samodzielnej zabawie, bez udziału w niej zajętych innymi sprawami rodziców.

Kolejnym z podjętych wątków badawczych było poznanie opinii na temat korzystania z obiektów sportowo-rekreacyjnych w najbliższej okolicy. Zdecydowana większość rodziców dzieci z niepełnosprawnością umysłową w stopniu lekkim (86\%) deklaruje, że ich syn/córka korzysta z infrastuktury sportowej. Rzadziej na obiektach sportowych bywają dzieci z niepełnosprawnością intelektualną w stopniu umiarkowanym (53,3\%). Najczęściej wymieniane są place zabaw $(90,2 \%)$, pływalnia $(85,3 \%)$ i boisko do gier sportowych $(60,9 \%)$. W pojedynczych wypowiedziach pojawiła się hala czy stadion sportowy, ścianka wspinaczkowa i lodowisko. Szczególną uwagę należy zwrócić na liczną grupę rodziców dzieci z umiarkowaną niepełnosprawnością intelektualną (46,7\%), którzy poświadczyli, że nie korzystają z infrastuktury sportowej. Jako przyczyny takiego stanu ankietowani podawali przede wszystkim: brak odpowiednich obiektów w najbliższej okolicy, oferty niedostosowane do potrzeb i możliwości ich dziecka, jego niesamodzielność, problemy zdrowotne, także trudności finansowe.

Analizowane badania empiryczne dotyczyły również opinii rodziców na temat roli, jaką odgrywa lub powinna odgrywać szkoła

${ }^{13}$ R. Piętka, B. Matacz, Czynniki środowiska rodzinnego wptywające na osobowość $i$ edukacje szkolna dzieci upośledzonych umysłowo, http://www.profesor.pl serwis edukacyjny [dostęp: 23.04.2017]. 
w zakresie kształtowaniu zachowań wolnoczasowych dzieci i młodzieży. Podjęto zatem problem zajęć dodatkowych prowadzonych przez szkołę oraz zadań środowiska szkolnego odnośnie do organizowania uczniom czasu wolnego. Większość (68\%) ankietowanych rodziców zapewnia, że ich dziecko uczestniczy w zajęciach pozalekcyjnych. Najpopularniejsze okazały się takie formy jak koła zainteresowań (Ja i dźwięki, muzyczne, czytelnicze, plastyczne, kulinarne, taneczne), zajęcia artystyczne, rewalidacyjne (usprawnianie wad wymowy, koordynacja zmysłów, usprawnianie technik szkolnych, poprawa wad postawy) oraz wyrównujące szanse edukacyjne. $32 \%$ ankietowanych rodziców stwierdza, iż ich dziecko nie uczestniczy w zajęciach dodatkowych. Przyczynami rezygnacji okazują się: niedogodne godziny $(33,3 \%)$, brak ochoty $(33,3 \%)$ oraz zmęczenie dziecka (16,6\%). Dla rodziców dzieci z umiarkowaną niepełnosprawnością intelektualną decydująca okazała się również nieciekawa oferta zajęć $(40,0 \%)$ oraz odległość od miejsca zamieszkania.

Badani rodzice niemalże jednomyślnie $(94,7 \%)$ twierdzą, że szkoła powinna pomagać im w zakresie organizowania dzieciom czasu wolnego. Jako oczekiwane działania wspierające wskazywali pośrednictwo $\mathrm{w}$ poszukiwaniu informacji na temat propozycji spędzania czasu wolnego osób niepełnosprawnych, przygotowywanie festynów rodzinnych, organizowanie zajęć na obiektach sportowych lub wycieczek krajoznawczych do ciekawych miejsc. Wielu rodziców zgłaszało także potrzebę organizowania przez szkołę czasu wolnego dzieci podczas ferii zimowych i wakacji letnich w formie kilkudniowych wyjazdów lub półkolonii. Opinie rodziców na temat udziału szkoły w organizowaniu czasu wolnego nie różnicował stopień niepełnosprawności intelektualnej dziecka.

Ważnym elementem czasu wolnego są także zajęcia pozaszkolne. Pozytywnie należy interpretować fakt, że zdecydowana większość rodziców dzieci z umiarkowaną niepełnosprawnością intelektualną $(78,4 \%)$ deklaruje udział swoich synów/córek w zorganizowanych formach spędzania czasu wolnego poza szkołą. Nieco rzadziej korzystają z nich dzieci z niepełną sprawnością intelektualną w stopniu lekkim (51,6\%). Najczęściej deklarowanymi formami okazały się 
zajęcia sportowe $(33,3 \%)$. Ponadto ankietowani rodzice wymieniali również zajęcia logopedyczne $(57,1 \%)$, rehabilitacyjne $(28,6 \%)$ oraz terapię zajęciową SI (23,8\%), które jednak (zgodnie z przyjętą definicją) nie mają charakteru zajęć wolnoczasowych.

Ostatnim z analizowanych wątków badawczych był problem nadzoru rodzica lub opiekuna nad spędzeniem wolnego czasu. Wszyscy ankietowani rodzice deklarują, że wiedzą, co ich dziecko robi w czasie wolnym i z kim go spędza. Jest to pomyślna i oczekiwana sytuacja, gdyż brak takiej kontroli może powodować, że dziecko nieodpowiednio i nieracjonalnie spędzi czas, ulegając niekoniecznie dobrym wpływom rówieśników lub osób, które chce naśladować. Czas wolny każdego dziecka, a niepełnosprawnego szczególnie, musi podlegać w bardzo dużym stopniu określonym rygorom i racjom ustalonym przez dorosłych. Współtowarzyszami zachowań wolnoczasowych dziecka z niepełną sprawnością umysłową najczęściej są rodzice $(95,3 \%)$, rodzeństwo $(71,4 \%)$ lub inni członkowie rodziny $(66,7 \%)$. Wyniki przeprowadzonych badań dowodzą, że stopień niepełnosprawności intelektualnej dziecka jest czynnikiem różnicującym opinie rodziców na temat udziału rówieśników w zachowaniach wolnoczasowych. Zdecydowanie częściej koleżanki i kolegów jako towarzyszy czasu wolnego wskazali rodzice dzieci niepełnosprawnych intelektualnie $w$ stopniu lekkim (56,7\%). W odniesieniu do dzieci z umiarkowaną niepełnosprawnością intelektualną było to zaledwie $4,8 \%$ rodziców.

\section{Zakończenie}

Wyniki przeprowadzonych badań empirycznych potwierdzają dużą ilość czasu wolnego, jaką dysponują dzieci z niepełnosprawnością intelektualną. W tej sytuacji konieczne są szerokie działania szkoły, środowiska rodzinnego, społecznego, a także samych pedagogów specjalnych, aby czas wolny stał się ważnym elementem procesu rewalidacji dziecka $\mathrm{z}$ niepełną sprawnością umysłową. 
Każde działania indywidualne bądź zajęcia grupowe organizowane w czasie wolnym mogą mieć wartość oddziaływania rehabilitacyjnego. Przy zapewnieniu ze strony otoczenia odpowiedniej stymulacji pobudzona zostanie aktywność własna dziecka z niepełnosprawnością intelektualną, które zwykle jest jednostką bierną. Zaburzone procesy myślowe, trudności przystosowawcze skutecznie blokują ujawnianie przez dzieci niepełnosprawne zdolności, umiejętności, które tylko poprzez właściwe działania wychowawcze mogą być wydobyte. Dobrze zorganizowany i spędzony czas wolny jest właśnie tą sferą, która może rekompensować wszystkie inne niepowodzenia, dawać satysfakcję i radość życia, może zaspokajać potrzebę twórczości, przynależności, ekspresji i działania. Czas wolny jawi się zatem jako teren nieograniczonych możliwości rehabilitacyjnych, dlatego powinien zajmować jedno z czołowych miejsc zarówno w badaniach naukowych, jak i (a może przede wszystkim) w praktycznych działaniach na rzecz dzieci z niepełnosprawnością intelektualną.

\section{Bibliografia}

Borzyszkowska H., Zajęcia pozalekcyjne i poza szkolne oraz czas wolny dzieci upośledzonych umystowo, [w:] Upośledzenie umystowe, pedagogika, red. K. Kirejczyk, PWN, Warszawa 1981.

Czajkowski K., Wychowanie do rekreacji, WSiP, Warszawa 1979.

Czajkowski K., Wychowanie do rekreacji, Wydawnictwa Szkolne i Pedagogiczne, Warszawa 1979.

Dykcik W., Tendencje rozwoju pedagogiki specjalnej. Osiagnięcia naukowe i praktyka, Wydawnictwo Naukowe Polskiego Towarzystwa Pedagogicznego, Poznań 2010.

Gracz J., Sankowski T., Psychologia w rekreacji i turystyce, Akademia Wychowania Fizycznego w Poznaniu, Poznań 2001.

Jegier A., Wprowadzenie, [w:] Czas wolny matych dzieci w świecie realnym $i$ wirtualnym, ed. by A. Jegier, Difin SA, Warszawa 2016.

Kusztelak A., Ląg K., Czas wolny młodzieży aksjologicznym dylematem edukacji dla bezpieczeństwa, [w:] Edukacja dla bezpieczeństwa. Interdyscyplinarne konteksty i dylematy, red. Z. Dziemanko, A. Kusztelak, Wydawnictwa Naukowe Wyższej Szkoły Handlu i Usług, Poznań 2010. 
Parchomiuk M., Sposoby spędzania czasu wolnego przez młodzież upośledzona umysłowo w stopniu lekkim i sprawna umysłowo, "Wychowanie Na co Dzień” 2000, nr 4/5, s. 13-16.

Piętka R., Matacz B., Czynniki środowiska rodzinnego wptywające na osobowość i edukacje szkolna dzieci upośledzonych umysłowo, http:/ / www.profesor.pl education website [dostęp: 23.04.2017].

Ploch L., Jak organizować czas wolny dzieci i młodzieży upośledzonych umystowo, WSiP, Warszawa 1992.

Tauber R.D., Siwiński W., Pedagogika czasu wolnego, Wyższa Szkoła Hotelarstwa i Gastronomii, Poznań 2002.

Zimny J., Czas wolny wyzwaniem rodziny w kształtowaniu osobowości osób niepetnosprawnych, [w:] Rodzina w oczach społeczeństwa, red. J. Zimny, Katolicki Uniwersytet Lubelski Jana Pawła II w Lublinie, Stalowa Wola 2013.

Żółkowska T., Aktywność pozadydaktyczna uczniów z lekkim stopniem upośledzenia umysłowego a poziom opieki rodziców nad ich czasem wolnym, "Zeszyty Naukowe. Prace Instytutu Pedagogiki i Psychologii" 1995, nr 21. 